\title{
EVIDENCE FOR HEADWALL WEATHERING ZONES, BOUNDARY GLACIER, CANADIAN ROCKY MOUNTAINS
}

\author{
BY JAMES S. GARDNER
}

(Department of Geography, University of Waterloo, Waterloo, Ontario N2L 3G1, Canada)

ABSTRACT. Temperature records from several randkluft sites at the margins and headwall of Boundary Glacier (lat. $52^{\circ} 12^{\prime} \mathrm{N}$., long. $117^{\circ} 12^{\prime} \mathrm{W}$.) in the Canadian Rocky Mountains are presented. These records indicate that during the ablation season a diurnal freeze-thaw air and rocksurface temperature regime occurs in a $2 \mathrm{~m}$ wide zone centred on the randkluft lip. Deeper in the randkluft, stable sub-zero conditions prevail whereas above the randkluft an above-freezing temperature regime prevails. The freeze-thaw temperature regime, observed freezing of melt water and rain water on randkluft rock surfaces, and copious in-situ loose weathering products on the headwall and marginal free faces suggest an active frost-shattering environment. Downslope migration of the randkluft lip during the ablation season results in a migration of the freeze-thaw zone and thus a seasonal extension of the rock surface area exposed to the favorable weathering environment. Longer-term glacier fluctuations, with attendant thinning and thickening of the ice body, could result in large areas of marginal and headwall rock surfaces being exposed to the randkluft weathering environment over long periods of time. The data and observations from Boundary Glacier support an idea, suggested by Battle (1960), that open and shallow randklufts, rather than closed and deep bergschrunds, are a focus of weathering at glacier margins and thus a potential factor in cirque development.

\section{INTRODUCTION}

On the basis of field measurements, Battle (1960) cast doubt on the prevailing bergschrund hypothesis of cirque formation. He suggested that open randklufts rather than closed, deep bergschrunds are focal zones for frost-shattering. This is an idea that has not been field tested substantially since his research and serves as a point of departure for this paper.

In support of this idea, temperature data were gathered at "Boundary Glacier" (unofficial name) in the Canadian Rocky Mountains (lat. $52^{\circ} 12^{\prime}$ N., long. $117^{\circ} 12^{\prime}$ W.) (Fig. 1). Boundary Glacier has been the site of sediment-budget research since 1982. As part of the research, processes which supply debris to the glacier in the headwall and marginal zones were observed and measured. Initial observations revealed large quantities of loose, weathered bedrock on the bounding mountain slopes. The data presented here are derived from an attempt to understand the origin of this material.

\section{RESEARCH CONTEXT}

Four related areas of high mountain and periglacial research pertain. First, weathering zones at glacier headwalls have been integral to explanations of cirque formation

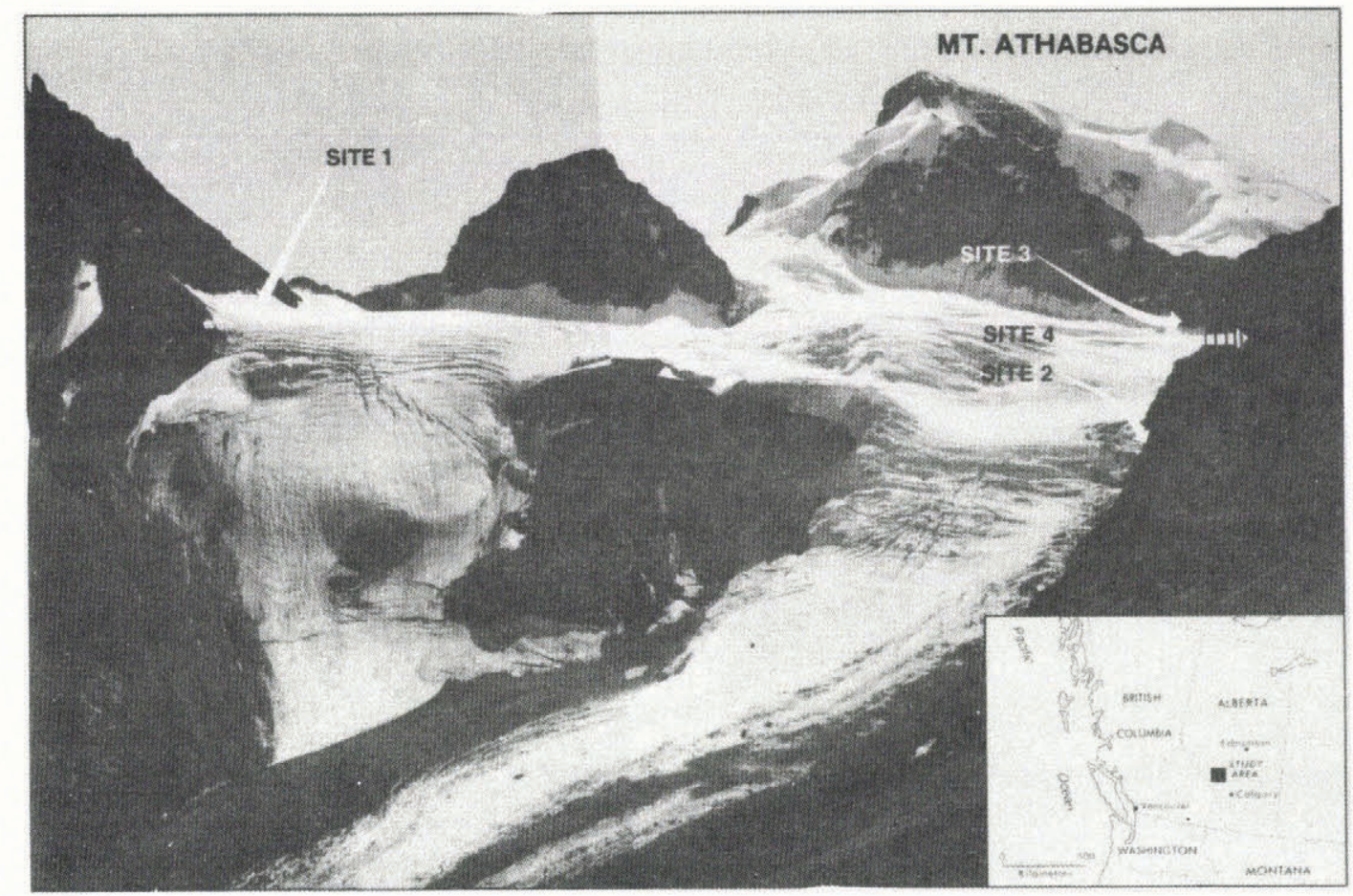

Fig 1. The Boundary Glacier study area and measurement sites. 
(Johnson, 1904). Secondly, intensified physical weathering has been indicated for the vicinity of late-lying snow patches (e.g. Lewis, 1939). Thirdly, weathering in the vicinity of snow and ice patches on mountain free faces has been presented as an important factor in low-magnitude/ high-frequency rockfall (Gardner, 1970, 1983). In most situations it has been thought that freezing and thawing temperatures in the presence of moisture are the driving force in frost-shattering in suitable rock types. Fourthly, considerable experimental research (e.g. Lautridou and Ozouf, 1982) and discussion (e.g. McGreevy and Whalley, 1982) have attempted to resolve the mechanisms of frostshattering as a weathering form.

Johnson (1904) was one of the first to propose intensified frost-shattering in bergschrunds as leading to cirque development. Lewis (1938) and Nussbaum (1938) postulated that spring and summer melt water would trickle into the bergschrund where it would come in contact with cold rock, freeze, and produce frost-shattering of the rock. Johnson (1941) questioned this role of melt water in bergschrunds. Later, Battle and Lewis (1951) and Battle (1960) cast doubt on these ideas through their observations in deep bergschrunds where they found stable temperatures at or below freezing and little physical evidence of frost-shattering. Furthermore, they pointed out that, in temperate glaciers with basal ice at the pressure melting-point, melt water would be unlikely to freeze.

Fisher's (1953) research at high altitude in the Alps led to a suggestion that frost-shattering could occur in a narrow zone marking the boundary between cold and isothermal (temperate) ice. Priestley (1923), Lewis (1938), and Fisher (1955) postulated that a cirque wall hundreds of meters high could be produced by the migration of weathering zones up and down as glacier fluctuations occur. Finally, Battle (1960) suggested that the surficial glacier headwall boundary, marked by a randkluft, rather than the bergschrund is the focal zone for weathering.

This boundary is analogous to a snow-patch edge. Matthes (1900) and later, Lewis (1939) and McCabe (1939), described freeze-and-thaw and melt-water conditions in the vicinity of snow patches, suggesting intense physical weathering. Subsequent empirical research, including measurements of bedrock temperatures, by Gardner (1969), Fukuda (1971), Thorn (1979), and Ball (1980) indicated a suitable thermal and moisture environment for weathering in the vicinity of mountain snow patches during spring and summer at least. Furthermore, a direct association between the presence of snow and ice patches on steep mountain free faces and rockfall frequency was demonstrated (Rapp, 1960; Gardner, 1970, 1983).

The identification of zones of freeze and thaw at glacier and snow-patch margins is an important research accomplishment. However, the direct relationships between freezing and thawing temperatures, the presence of moisture, rock type, and frost-shattering of bedrock remain poorly understood (McGreevy, 1981; McGreevy and Whalley, 1982; Thorn, 1982; Whalley and others, 1984; Whalley and McGreevy, 1985). Indeed, Thorn (1982) suggested that frostshattering is a much more restricted process than is generally stated in the geomorphic literature and that other forms of physical and physico-chemical weathering could bear closer examination.

Within the above research context, this paper addresses four points with respect to weathering zones in the vicinity of randklufts: the thermal conditions, the moisture conditions, weathering-zone migration, and physical evidence of weathering as demonstrated at Boundary Glacier.

\section{BOUNDARY GLACIER}

Boundary Glacier is a cirque glacier of about $2 \mathrm{~km}$ in length and covering an area of $1.5 \mathrm{~km}^{2}$ (Fig. 1). Its unofficial name derives from its location near the drainage divide between the Saskatchewan and Athabasca watersheds which also marks the boundary between Banff and Jasper National Parks. The glacier rises at $3320 \mathrm{~m}$ a.s.l. as a leeslope cornice and hanging glacier on Mount Athabasca. It descends through a low-gradient accumulation basin at $2750 \mathrm{~m}$ a.s.l. and an ice fall at $2500 \mathrm{~m}$, to two ice tongues, the lower of which is marked by a debris-covered terminus at $2365 \mathrm{~m}$ a.s.1. The equilibrium-line altitude is at about $2730 \mathrm{~m}$. Accumulation is by direct snowfall, wind drift, and snow avalanching from the confining slopes on Mount Athabasca and its subsidiary peaks. Melt-water discharge occurs supraglacially, subglacially, and marginally.

The Holocene record of glacial fluctuation at Boundary Glacier conforms with the general outline proposed for the Canadian Rockies by Luckman and Osborn (1979). The present glacier is a product of the Neoglacial which commenced shortly before 4000 years B.P. at this location (Gardner and Jones, 1985). Boundary Glacier probably persisted in its early Neoglacial extent throughout much of the subsequent 4000 years and achieved a maximum sometime in the last 250 years during the Cavell Advance (Little Ice Age). The maximum is marked by a well-developed end moraine from which Boundary Glacier has receded $850 \mathrm{~m}$ in the past century.

A sequence of air photographs beginning in 1938 details some of this recession. By 1938, the glacier had receded about $150 \mathrm{~m}$ and had down-wasted about $50 \mathrm{~m}$ at its terminus. By 1966, a further recession of $620 \mathrm{~m}$ had occurred but between 1966 and the mid 1970s a re-advance of about $40 \mathrm{~m}$ took place. In the last decade a further recession of $80 \mathrm{~m}$ from the 1966 position has occurred. Lateral moraine positions in the area of the 1985 terminus indicate a down-wasting of $90-120 \mathrm{~m}$.

Vertical fluctuations of the glacier surface in areas bounded by bedrock may be an important factor in extending the spatial extent of weathering zones over long periods of time. The extent of these fluctuations on Boundary Glacier through the Holocene is difficult to determine on the basis of field evidence. There is no clear distinction of varying degrees of physical weathering at various levels on the headwall and marginal rock surfaces. Everywhere, including surfaces exposed within the randklufts, the bedrock is jointed, broken, and cracked. Small accumulations of fines are present on flat-lying surfaces. Interpretation of air photographs reveals a total down-slope migration of $10-15 \mathrm{~m}$ in the level of the headwall randkluft at Boundary Glacier since 1938.

Given the importance of rock type and condition as factors in most types of weathering (Whalley and McGreevy, 1985), a brief consideration of rockwall geology at Boundary Glacier is warranted. Upper Devonian and Mississippian limestones, dolomites, and shales are the predominant rock types in the vicinity of Boundary Glacier. The measurement sites (Fig. 1) were located in the Mississippian Banff Formation of bedded limestones and laminated calcareous mudstones. At site 2, this unit grades into bedded black limestones and fissile shales of the Exshaw Formation. At site 3, immediately above the measurement site is the contact with the Rundle limestones and dolomites. The Banff and Rundle Formations in the Boundary Glacier area are flat-lying or gently dipping to the south-west, resulting in exposure of bedding planes on the steep rockwalls of the study area. These formations are known throughout the Rockies as rockfall source areas with the Banff Formation being the more recessive of the two. The implication is that these rock types and their stratigraphic arrangement is favorable for physical weathering.

Boundary Glacier has well-developed marginal and headwall randklufts and bergschrunds (Fig. 1). The randklufts, separating the snow and ice from the adjacent rockwall, are usually open and subject to atmospheric influences by late June or early July. The bergschrunds are best developed in avalanche-fed cones and aprons at the glacier headwall, and are similar to that described in an avalanche-cone glacier elsewhere in the Canadian Rockies by Osborn (1983).

\section{DATA COLLECTION}

Data collection focussed on marginal and headwall randklufts in 1983 (sites 1 and 2) and 1984 (site 3), and a small headwall bergschrund which graded into a randkluft in 1985 (site 4) (Fig. 1). Continuous and periodic recording instruments provided a record of air temperature in and adjacent to the randklufts. The choice of locations was 
based on two factors. The first was a suitable randkluft with some protection from objective hazards such as rockfalls and snow avalanches. The second factor was the intention to collect data representing different aspects (exposures) and situations where active weathering would be expected given findings of previous research (e.g. Battle, 1960).

Ryan thermographs were suspended in the randklufts between 7 July and 14 August 1983 at site 1 and between 18 July and 18 August 1983 at site 2, at altitudes of $2755 \mathrm{~m}$ and $2570 \mathrm{~m}$, respectively. The positioning of the sensors in the randkluft at a depth of $2 \mathrm{~m}$ was conditioned by the findings of previous research which suggested that an active freeze-and-thaw environment may be located in the area immediately up- and down-slope of the randkluft lip. At site 1 there was a rapid down-slope migration of the randkluft lip which, in the first 3 weeks of record, resulted in temperature data representing a vertical zone of about $4 \mathrm{~m}$ in relation to the lip. Down-slope migration at site 2 occurred much more slowly such that the sensor location remained below the randkluft lip throughout the measurement period. The site 1 sensor was not re-located in the randkluft during the measurement period. While the stranding of the site 1 thermograph above the randkluft is regarded as a negative aspect of the data collection, in some respects it demonstrated the dynamic nature of the randkluft location and the changing thermal conditions associated with this dynamism.

In 1984, a Ryan thermograph was suspended in the headwall randkluft (site 3) (Fig. 1) from 23 July to 18 August. The altitude of this site is $2910 \mathrm{~m}$. This thermograph provided a continuous record of temperature in a zone from $1.5 \mathrm{~m}$ below the randkluft lip to just above the lip. The downward migration $(1.5-1.0 \mathrm{~m})$ of the randkluft lip exposed the sensor to direct solar radiation in early August (Fig. 2) and the instrument was lowered into the randkluft on 4 August where it remained until 18 August.

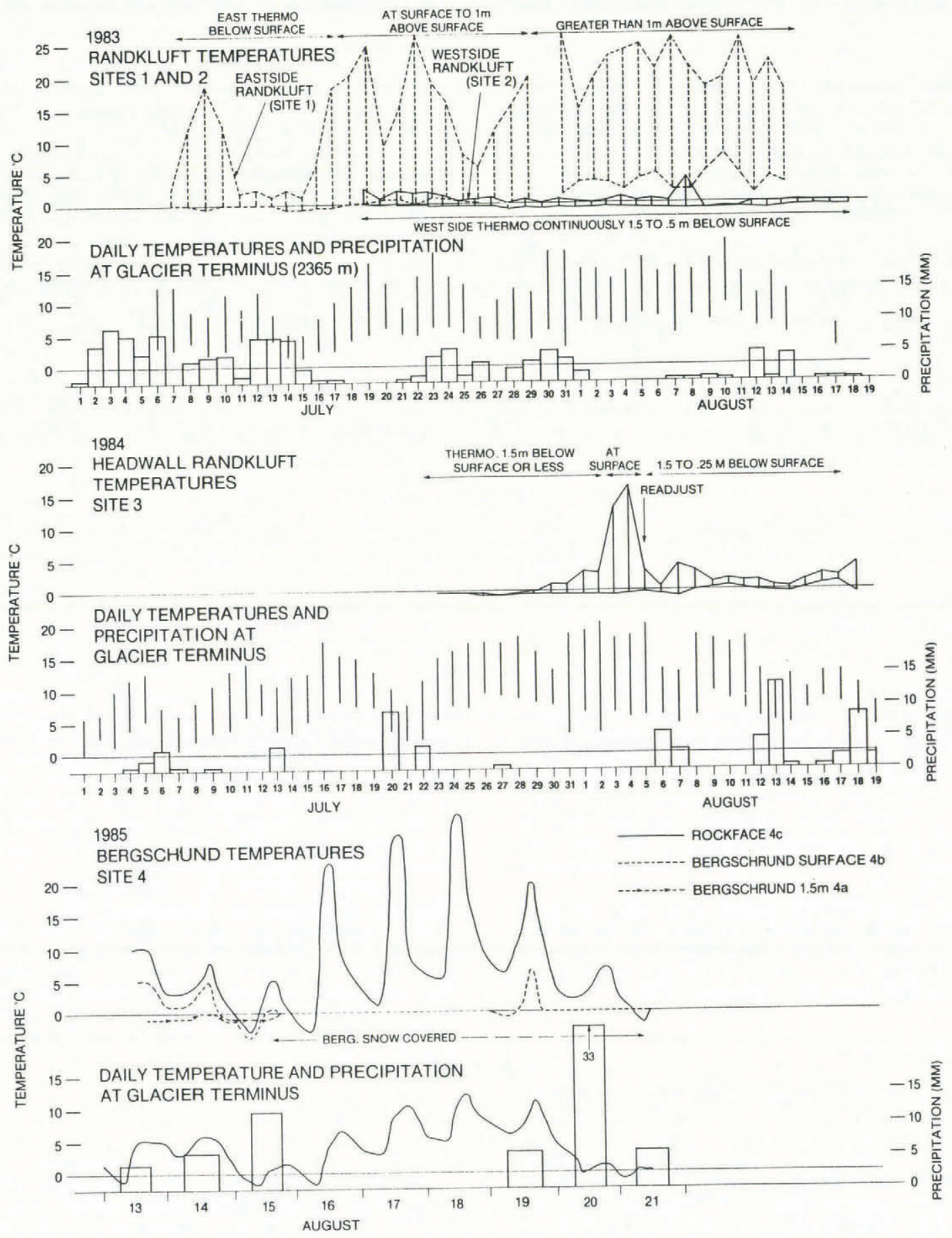

Fig. 2. Randkluft air temperatures and glacier-terminus temperatures and precipitation. 
Measurements in 1985 were made with a Grant multilead temperature recorder over a $9 \mathrm{~d}$ period between 13 August and 21 August. Measurements were made using three leads in and adjacent to a small bergschrund (site 4 , Fig. 1) which intersects a spur of the headwall and thus, by definition, becomes a randkluft. Site 4 altitude is $2875 \mathrm{~m}$. One sensor was placed at a depth of $2 \mathrm{~m}$ in the bergschrund. Another was placed at the surface of the bergschrund. The third sensor was placed on the rock surface about $10 \mathrm{~m}$ above the bergschrund and $3 \mathrm{~m}$ above the snow-rock boundary. The former two sensors provided air temperatures immediately adjacent to the snow or ice surfaces. The latter sensor provided rock-surface temperatures. Unfortunately, much of the short observation period was characterized by snowy, cold weather and therefore was not characteristic of the usually more clement conditions of the ablation season. Nonetheless, the data effectively demonstrate the impact of such weather on glacier-margin temperature conditions and freeze-thaw activity.

\section{RESULTS}

The results take two forms: quantitative data describing temperature conditions at the measurement sites; and qualitative observations of randkluft migration, moisture conditions, and weathering products on the marginal and headwall rock surfaces. Temperature data are summarized in Table I. In Figure 2, temperature series are presented in relation to meteorological conditions as recorded at the glacier terminus. Figure 3 gives examples of diurnal temperature curves at different sites and under different meteorological conditions. The following discussion of the temperature data focusses on several points, including: comparisons between sites, relationships between glaciermargin and headwall temperatures and meteorological conditions, and the definition of freeze-thaw zones. All sites, with the exception of site $4 a$ (bergschrund $2 \mathrm{~m}$ ), experienced some freeze-thaw activity during the observation periods (Table I). In 1983, site 1 experienced a large daily temperature range and high daily maximum temperatures, whereas site 2 was characterized by a small range and relatively low daily maxima and minima (Table I; Figs 2 and $3 \mathrm{~b}$ ). The latter site experienced more daily frost cycles, frost alternation days, and a longer mean daily duration of sub-freezing temperatures. Site 1 did not experience sub-freezing temperatures after the sensor was exposed above the randkluft lip, although daily minima were $4-5^{\circ} \mathrm{C}$ lower than the minima recorded at the glacier

\section{TABLE I. SUMMARY STATISTICS FOR TEMPERATURE CONDITIONS AT RANDKLUFT \\ SITES}

Site 1 Site 2 Site $3 \quad$ Site $4 a$ Site $4 b \quad$ Site $4 c$

Days of observation
Mean daily maximum
temperature $\left({ }^{\circ} \mathrm{C}\right)$
Mean daily minimum
temperature $\left({ }^{\circ} \mathrm{C}\right)$
Modal time of
maximum (h)
Modal time of
minimum (h)
Number of daily
frost cycles
Number of partial
frost cycles
Mean daily duration of
freezing temperature (h)
Frost-alternation days
Frost-free days
Ice days
Maximum rate of freezing
(deg min ${ }^{-1}$ )
Maximum rate of thawing

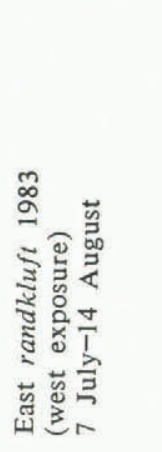

39

1.5

$16.00-$

17.30

04.00-

07.00

5

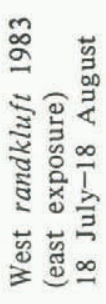

32

0.5

$-0.6$

$14.00-$

15.30

$00.00-$

07.00

17

3

7

8

31

0

0.022

0.028

0.028

0.04

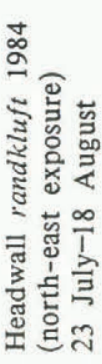

27

2.2

$-0.3$

$11.30-$

14.00

00.00-

08.30

11

4

14

15

5

7

13

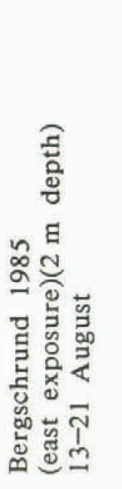

9

0

$-0.2$

$11.30-$

14.00

$00.00-$

07.00

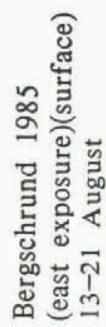

9

2.0

$-0.6$

$12.30-$

14.30

04.00-

07.00

07.00 
15- HEADWALL RANDKLUFT 1984 (SITE 3)
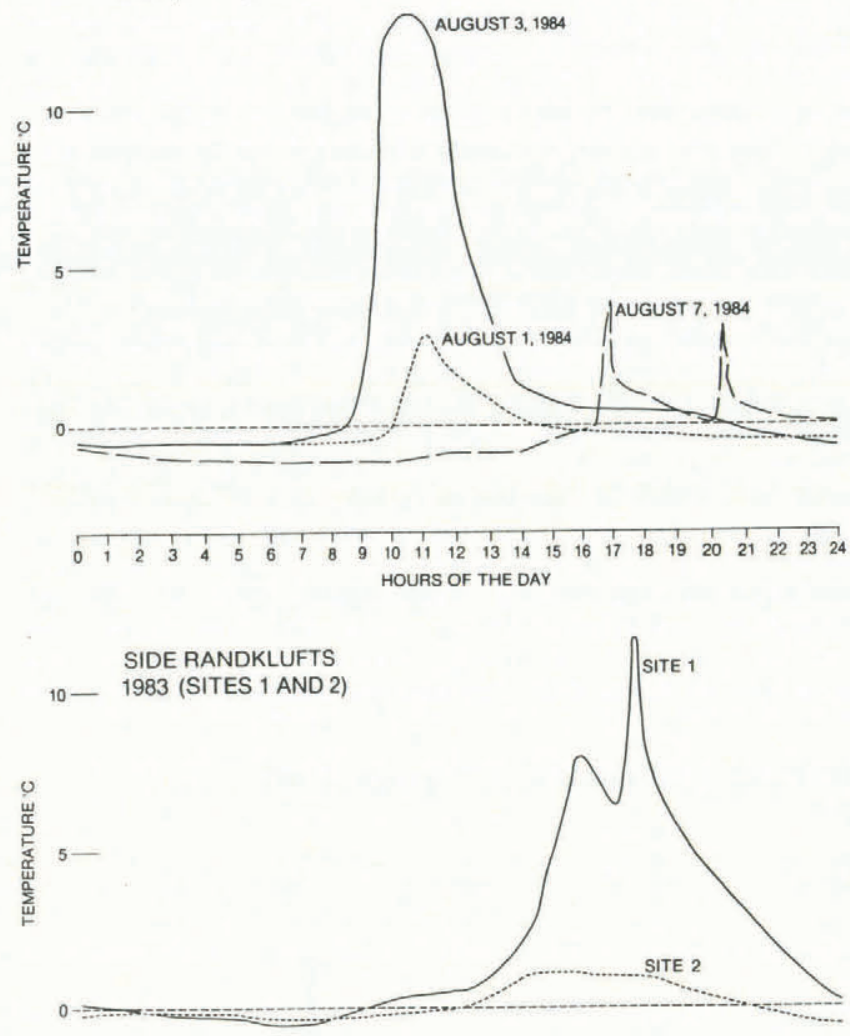

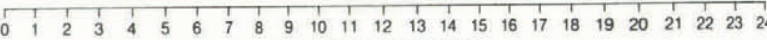
HOURS OF THE DAY

Fig. 3. Examples of diurnal air-temperature regimes at randkluft sites under differing meteorological conditions.

terminus. This difference probably reflects the elevation and ground-surface condition contrasts between site 1 and the glacier terminus.

The sensor at site 2 remained below the randkluft lip throughout the measurement period, recording daily maxima and minima slightly above and below $0^{\circ} \mathrm{C}$ (Table I). Over half of the recording days were frost alternation days and no frost-free days occurred. The contrasts in temperature conditions at sites 1 and 2 , which have approximately the same altitudes, may be attributed to exposure and nonexposure above the randkluft, to slope aspect and exposure to sunlight, and to specific site conditions including the presence and absence of moisture. The westerly exposure to direct solar radiation during mid-day and the afternoon resulted in intense heating of the rock surface and adjacent air at site 1. This is reflected in the record of air temperature immediately adjacent to the rock surface between 7 and 15 July (Fig. 2) and that shown in Figure $3 \mathrm{~b}$ for 27 July when the recorder was beneath or slightly above the randkluft lip. Daily maxima are high (Table I); indeed, they are in excess of screen temperatures at the glacier terminus. Daily minima are low (Table I) as a result of high night-time radiative losses at this altitude and the randkluft micro-environment. In contrast, the site 2 sensor was never exposed to direct sunlight and the adjacent surfaces on this north-easterly aspect were exposed to solar radiation only in the early morning hours and remained in shade from at least mid-day on. Furthermore, site 2 was a relatively moist environment with frequent drainage of melt water from up-slope snow patches into the randkluft. In contrast, the rock surfaces at site 1 were dry except after snow and rain events. The importance of exposure to direct solar radiation is exemplified further by the temperature record at site 1 during cloudy, cool conditions (11-15 July; Fig. 2) when the low maxima and freezing to sub-freezing minimum temperature pattern more characteristic of site 2 prevailed.

The temperature record from the headwall (site 3 ) in 1984 appears to be a mix of the site 1 and 2 records (Fig. 2; Table I). Down-slope migration of the randkluft lip exposed the temperature sensor to direct solar radiation between 3 and 5 August, giving rise to high daily maximum temperatures while night-time minima remained low, as at site 1 . Using 1 and 3 August data, Figure $3 \mathrm{~b}$ illustrates the effect of direct solar radiation. The thermograph was adjusted on 5 August to a level $1.5 \mathrm{~m}$ below the randkluft lip and a temperature record similar to that at site 2 prevailed for the remainder of the measurement period. Site 3 is characterized by a large number of freeze-thaw cycles (Table I) with 15 of the 27 observation days being classed as frost-alternation days. The early modal time of daily maximum temperature $(11.30-14.00 \mathrm{~h})$ contrasts especially with that at site 1 and reflects the influx of direct solar radiation during the morning and afternoon shading on this north-eastern exposure.

The 1985 data from site 4, although short-term, show some interesting contrasts between the within and outside bergschrund locations. Air temperatures at $2 \mathrm{~m}$ depth in the bergschrund fluctuated very little, remaining at and just below $0^{\circ} \mathrm{C}$ throughout the 13-21 August period (Fig. 2; Table I). Air temperatures at the surface of the bergschrund fluctuated more markedly with three of the nine days being classified as frost-alternation days. Mean daily maximum temperature was $2.0^{\circ} \mathrm{C}$ and mean daily minimum temperature was $-0.6^{\circ} \mathrm{C}$, a range similar to that found at sites 2 and 3. Above the bergschrund (site 4c), the rock-surface temperature regime was more similar to that at site 1 with some very high maxima $\left(35^{\circ} \mathrm{C}\right)$, reflecting direct solar radiation. Night-time cooling produced sub-freezing minima on four of the nine days. Extremely variable meteorological conditions in the 13-21 August period had a significant impact on the data, illustrating the effects of some meteorological controls on the randkluft/bergschrund environment.

Relationships between general meteorological conditions, as measured at the glacier terminus, and the temperature regimes at the glacier headwall and margins are graphically illustrated in Figure 2. Since the glacier terminus is at $2365 \mathrm{~m}$, as compared to the higher elevations of the other sites, the screen data may overestimate and underestimate air-temperature maxima and minima at these sites. In general, temporal trends and patterns of temperature and precipitation are consistent throughout the glacierized part of Boundary basin. Glacier-margin and headwall temperatures above the randkluft follow the same patterns as air temperature. Direct exposure to solar radiation magnifies maxima at the rock surface and in the air within a few centimeters of the surface over screen-recorded ( $1.5 \mathrm{~m}$ above surface) maxima as would be expected (Thorn, 1982).

The relationship between temperatures at screen level and within the randklufts is not so clear (Fig. 2). Data for 1 August 1984 (Fig. 3a) indicate that temperature variation at and below the randkluft lip is much reduced from that in the air and on or within a few centimeters of rock surfaces above the randkluft. At depths greater than $1 \mathrm{~m}$ in the randklufts or bergschrund, diurnal air-temperature variations are largely removed. This is most obviously illustrated by the 1985 data at site $4 \mathrm{a}$ where little temperature variation was indicated and no temperatures greater than $0{ }^{\circ} \mathrm{C}$ were recorded (Fig. 2).

Cloudy conditions subdued the daily variation in air temperatures at screen level and at or adjacent to rock surfaces directly above the randklufts. However, the effect of cloud cover may be obscured by the rain or snow which invariably accompanies cloudy conditions during the summe in the Rockies. For example, the impact of warm rain is illustrated by the data for 6 and 7 August 1984 at site 3 (Fig. 2). Both days experienced freezing and thawing temperatures in the randkluft. Rain began on 6 August and continued through 7 August. The maximum temperature on 7 August appears as a short-lived peak at $17.00 \mathrm{~h}$ and was followed by a similar though lesser peak at $20.30 \mathrm{~h}$ (Fig. $3 a)$. These peaks are interpreted to represent influxes of relatively warm rain water into the recording area. The longer-term impact of the warm rain was a general increase 
in minimum daily temperatures in the randkluft (Fig. 2). The pattern was repeated later from 13 to 19 August when prolonged warm rain occurred (Fig. 2).

During summer cyclonic precipitation events in the Rockies, snow of ten accompanies the cold-front passage at elevations above $2000 \mathrm{~m}$. The occurrence of snow and the development of a snow cover is reflected in the randkluft air-temperature data. A snow storm and snow cover on 14 August 1983 and after at site 2 produced uniform temperature conditions at and below $0^{\circ} \mathrm{C}$. Similarly, a fall of $15 \mathrm{~cm}$ of snow on 15 August 1985 removed temperature variations at sites $4 \mathrm{a}$ and $4 \mathrm{~b}$ for the following four days (Fig. 2). Uniform $0^{\circ} \mathrm{C}$ temperatures occurred beneath the snow cover until 18 August when the snow melted exposing the sensor at the bergschrund surface (site $4 \mathrm{~b}$ ). This resulted in a drop in temperature to $-1{ }^{\circ} \mathrm{C}$ during the night and a maximum temperature on 19 August of $6.5^{\circ} \mathrm{C}$ (Fig. 2). Late on 19 August, more snow was received and the $0^{\circ} \mathrm{C}$ isothermal conditions were re-established beneath the snow cover. The reduction of freeze-thaw activity produced by these periodic summer snow storms must be replicated by snow at other times of the year, reducing the amplitude of temperature variation and the probability of freeze-thaw activity in the randklufts.

The temperature data presented here allow some reflection on factors identified by prior research and discussion (e.g. Lautridou and Ozouf, 1982; McGreevy and Whalley, 1982) as being significant in frost-shattering. These factors include the rate, severity, duration, and frequency of freezing. Battle (1960) suggested that a freezing rate of 0.1 deg $\min ^{-1}$ was necessary for frost-shattering to occur in non-porous, cracked rock. Although this value has been applied as a comparative standard in subsequent research (e.g. Gardner, 1969), McGreevy (1981) and McGreevy and Whalley (1982) pointed out that such a freezing rate is unlikely to be achieved in Nature and that conditions under which it would occur have never been specified. The data from this study indicate freezing rates well below the 0.1 deg $\min ^{-1}$ threshold (Table I) and similar to the rates measured elsewhere in the Rockies (Gardner, 1969). These field data suggest caution in the use of the freezing-rate criterion for frost-shattering.

The Boundary Glacier data are, for the most part, indicative of relatively frequent, short-term (diurnal), and low-intensity freezing episodes (Table I). Some previous research (e.g. Thorn, 1979) has suggested that temperatures of $-4^{\circ}$ to $-10^{\circ} \mathrm{C}$ may be necessary for frost-shattering. At no time were such intensities recorded in this study. On the other hand, McGreevy and Whalley (1982) pointed out that factors such as rock type and freezing duration may influence the role of freezing intensity. Clearly, the formation of ice is of critical importance and observations at Boundary Glacier indicate at least superficial ice formation at low freezing intensities. This, and previous research cited by McGreevy and Whalley (1982), calls for caution in application of freezing-intensity thresholds for frost-shattering. The duration of freezing recorded in this study is generally short-term (i.e. less than $24 \mathrm{~h}$ ) (Table I) and this, coupled with the low intensities, may mitigate against frost-shattering. Thus, there is a clear need to extend measurements into seasons (spring, fall, winter) when longer duration and more intense freezing episodes would be expected. These may be more significant over the long term than the frequent, low-duration and low-intensity freezing episodes recorded during summer in this study.

Field observations provided information about the migration of the randkluft lip, the freezing of water within the randklufts and bergschrunds, and the presence of weathered rocks. Migration of the randkluft lip (see Fig. 4) was greatest at site 1 . From installation on 7 July to 24 July 1983, the lip migrated $3 \mathrm{~m}$ down-slope, exposing an equivalent vertical section of rockwall and the thermograph to direct solar radiation and atmospheric temperature regimes. Between 24 July and 14 August 1983 a further migration of $1.5 \mathrm{~m}$ occurred. At site 2 the total down-slope migration of the randkluft lip was $1.5 \mathrm{~m}$ between 19 July and 18 August 1983. Randkluft migration at site 3 between 23 July and 5 August 1984 was approximately $2.5 \mathrm{~m}$ and between 5 and 18 August it was $1 \mathrm{~m}$. The short observation period, as well as the snowfall, resulted in no observable change in the position of the bergschrund lip in 1985 .

Randkluft migration occurs through snow and ice ablation and by collapse of the ablating snow into the randkluft crevasse. The contrasting rates of migration at the various sites is a result of the different energy balances, the snow and ice conditions, and the development of a protective debris cover over the ablating snow and ice through melt-out and rockfall additions (Fig. 5). The fact that rand-

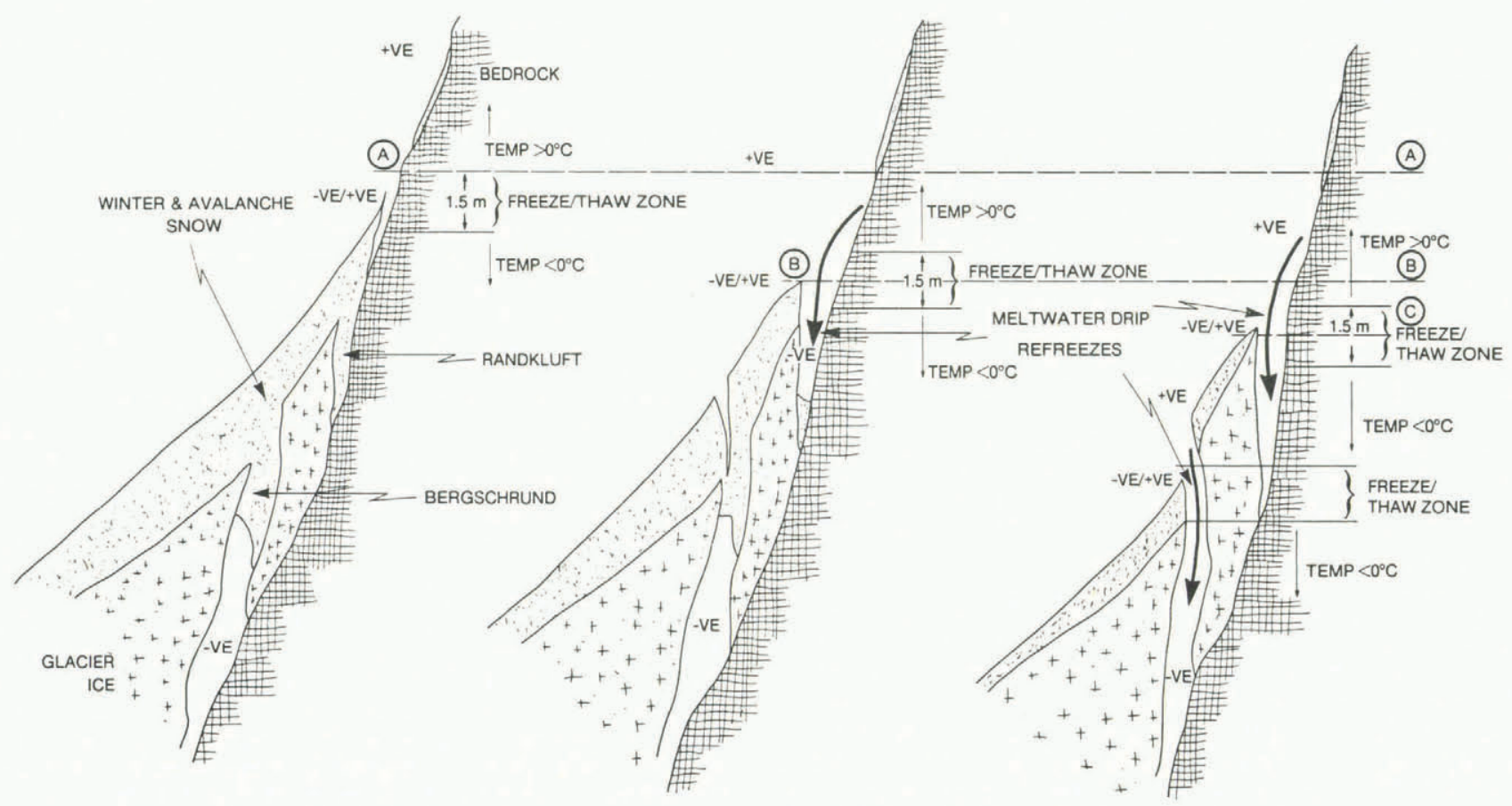

Fig. 4. Schematic representation of changing randkluft conditions during the summer ablation season. A. $B$, and $C$ represent the changing position of the randkluft lip. "+ve" and "-ve" represent the predominant temperature regimes at different positions relative to the randkluft. 


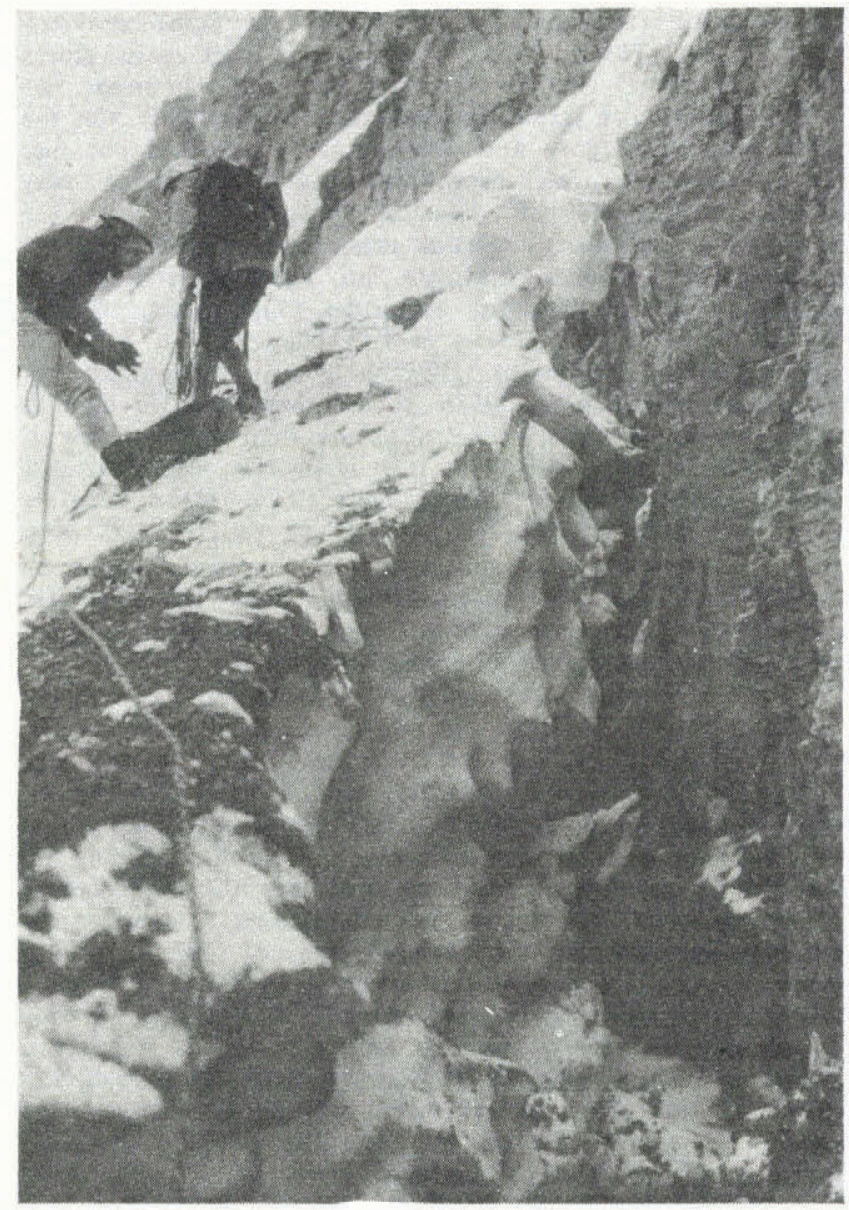

Fig. 5. Randkluft at site 3 in August 1984. Note the rockfall and melt-out debris on the snow surface. The accumulation of ice on the rock surface in the lower right of the photograph is melt water which has frozen in the sub-freezing randkluft environment.

kluft migration occurs during the ablation season results in exposure of a much larger area of bedrock to the freezethaw temperature regimes than would be the case with a static randkluft. This migration is shown graphically in Figure 4.

The freezing of melt water or rain water on rock and snow surfaces was observed on occasion at sites 2, 3, and 4. The existence of sub-freezing temperatures in the randklufts and bergschrund suggests that this should occur in the absence of supercooling. Furthermore, the open character of the randklufts results in atmospheric pressures pertaining, thus ruling out the question of pressure melting. The best evidence of water freezing on rock surfaces was found in the headwall randkluft (site 3) in 1984. Frozen water was observed on the bedrock below a depth of $1 \mathrm{~m}$ on all visits to site 3 (Fig. 5). This took the form of clear ice (verglace) on smooth rock surfaces, ice plugs in cracks in the bedrock, and icicles hanging from protruding rock and snow or ice surfaces. In most cases, the ice appeared to be the result of melt water flowing down the rock from melting snow above the level of the randkluft lip and freezing when it reached the colder conditions within the randkluft. This observation supports the hypothesis of Lewis (1938) and Nussbaum (1938) for the freezing of melt water and therefore enhanced frost-weathering, and provides some field data on availability of moisture at frost-shattering sites as called for by McGreevy and Whalley (1982). At the bergschrund site in 1985 (site 4), evidence of freezing of water took the form of icicles at levels below $0.25 \mathrm{~m}$ in the bergschrund and, at one point, a large plug of clear ice which blocked access to the lower reaches of the bergschrund.

Finally, the condition of bedrock surfaces at the study sites, and along the glacier margins generally, is indicative of active physical weathering. As noted earlier, much of the glacier margin and headwall intersects the thinly bedded and jointed limestones, dolomites, and shales of the Banff and Rundle Formations (Fig. 5). Previous studies of rockfall frequency and magnitude in the Canadian Rockies (Gardner, $1970,1983)$ indicate that these geological units are producers of copious rockfall and, by implication, are prone to physical weathering. McGreevy and Whalley (1982) pointed out that such in-situ "massive rock" is probably more susceptible to frost-shattering, due to the numerous bedding planes, joints, etc., than the smaller "intact rocks" such as those which constitute the rockfalls. Relatively few examples of clean, abraded, or polished bedrock surfaces are exposed at the margins of Boundary Glacier. Rather, in-situ "massive rock" is interrupted by bedding planes and joints. Where ledges are present, accumulations of "intact" fragments ranging from blocks to coarse sands occur. At the headwall, sections of "massive rock" are in various stages of detachment, resulting in very unstable surfaces which are easily disturbed by rockfall and snow-avalanche impact, and climbing. Adjacent snow and ice surfaces are invariably covered with rock debris (Fig. 5), indicative of the mass wasting of such weathering products.

\section{CONCLUSIONS}

This study adds to the empirical base of our understanding of specific weathering environments, one of the needs identified by McGreevy (1981) in his review of frost-shattering research. It also addresses the issue of rand$k l u f t$-centered weathering and erosion in the context of cirque development as raised by Battle (1960). The temperature data indicative of an active freeze-thaw regime, the observations of water freezing, and the weathered nature of marginal and headwall rock surfaces provide circumstantial and secondary evidence for a zone of physical weathering in the vicinity of the randkluft lip. The zone is dynamic in the sense that it migrates seasonally with the ablationrelated down-slope movement of the randkluft lip (Fig. 4). During winter, snow build-up closes the randkluft crevasse and moves the snow-rock boundary up-slope. This, and the general sub-zero air temperatures, subdues freeze-thaw activity. The winter build-up pre-conditions another downslope migration in the subsequent ablation season. By this means, the freeze-thaw regime and related moisture conditions are repeatedly extended over large areas of marginal and headwall rock surfaces. Further, by extending this phenomenon through the glacier fluctuations of the Holocene and Pleistocene, it is possible to envisage a situation where "hundreds of meters" (Priestley, 1923; Lewis, 1938; Fisher, 1955) could be exposed to favorable conditions for physical weathering and thus cirque development.

Although supportive of Battle's (1960) postulate, the data and information presented here are not conclusive and areas of further study are evident. Obviously, controlled laboratory experiments will continue to be useful in demonstrating the causal relationships between weathering and temperature, moisture, and rock types and conditions. Monitoring in the field of temperature, moisture, and rock combinations in micro-environments such as glacier margins will also be useful. In both field and laboratory situations, there is a need to observe weathering of "massive rock". Although it is often assumed that in such environments frost-shattering is the key weathering mechanism, researchers with an interest in glacier-margin weathering and erosion would do well to consider the wide range of physical and chemical weathering possibilities (McGreevy, 1981; Whalley and McGreevy, 1985). For example, many of the limestones adjacent to Boundary Glacier are susceptible to solution in rain and melt water. Small secondary deposits of calcite are found on bedrock surfaces in the vicinity of the randklufts and are indicative of chemical solution and subsequent deposition as precipitates or evaporites in subglacial and/or subaerial environments. In such a context, we need to know more about the interactions of chemical and physical weathering processes. 


\section{ACKNOWLEDGEMENTS}

I wish to thank N. Jones, E. Rozendaal, D. Whipp, A. Gouadon, and N. Gardner for their field assistance in carrying out the measurements. Parks Canada provided the necessary permits to carry out this and other research in Banff National Park. The Natural Sciences and Engineering Research Council of Canada provided funding through operating grant No. A9152 to J.S. Gardner.

\section{REFERENCES}

Battle, W.R.B. 1960. Temperature observations in bergschrunds and their relationship to frost shattering. (In Lewis, W.V., ed. Norwegian cirque glaciers. London, Royal Geographical Society, p. 83-95. (Research Series No. 4.))

Battle, W.R.B., and Lewis, W.V. 1951. Temperature observations in bergschrunds and their relationship to cirque erosion. Journal of Geology, Vol. 59, No. 6, p. 537-45.

Fisher, J.E. 1955. Internal temperatures of a cold glacier and conclusions therefrom. Journal of Glaciology, Vol. 2, No. 18 , p. $583-91$

Fisher, J.E. 1963. Two tunnels in cold ice at $4,000 \mathrm{~m}$. on the Breithorn. Journal of Glaciology, Vol. 4, No. 35, p. 513-20.

Fukuda, M. 1971. Freezing-thawing process of water in pore space in rocks. Low Temperature Science, Ser. A, Vol. 29, p. 225-29. [In Japanese with English summary.]

Gardner, J.S. 1969. Snowpatches: their influence on mountain wall temperatures and the geomorphic implications. Geografiska Annaler, Vol. 51A, No. 3, p. 114-20.

Gardner, J.S. 1970. Rockfall: a geomorphic process in high mountain terrain. Albertan Geographer, No. 6, p. 15-20.

Gardner, J.S. 1983. Rockfall frequency and distribution in the Highwood Pass area, Canadian Rocky Mountains. Zeitschrift für Geomorphologie, Bd. 27, Ht. 3, p. 311-24.

Gardner, J.S., and Jones, N.K. 1985. Evidence for a neoglacial advance of the Boundary Glacier, Banff National Park, Alberta. Canadian Journal of Earth Sciences, Vol. 22, No. 11, p. 1753-55.

Hall, K. 1980. Freeze-thaw activity at a nivation site in northern Norway. Arctic and Alpine Research, Vol. 12, No. 2, p. 183-94.

Hudec, P.P. 1973. Weathering of rocks in Arctic and sub-Arctic environment. (In Aitken, J.D., and Glass, D.J., eds. GAC-CSPG. Proceedings of the Symposium on the Geology of the Canadian Arctic, Saskatoon, May 1973. Waterloo, Ontario, University of Waterloo, p. 313-35.)

Johnson, D.W. 1941. Function of meltwater in cirque formation: a criticism. Journal of Geomorphology, Vol. 4, p. 253-62.
Johnson, W.D. 1904. The profile of maturity in alpine glacial erosion. Journal of Geology, Vol. 12, p. 569-78.

Lautridou, J.P., and Ozont, J.C. 1982. Experimental frost shattering: 15 years of research at the Centre de Géomorphologie du CNRS. Progress in Physical Geography, Vol. 6, No. 2, p. 215-32.

Lewis, W.V. 1938. A melt-water hypothesis of cirque formation. Geological Magazine, Vol. 75, p. 249-65.

Lewis, W.V. 1939. Snow-patch erosion in Iceland. Geographical Journal, Vol. 94, No. 2, p. 153-61.

Luckman, B.H., and Osborn, G.D. 1979. Holocene glacier fluctuations in the middle Canadian Rocky Mountains. Quaternary Research, Vol. 11, No. 1, p. 52-77.

McCabe, L.H. 1939. Nivation and corrie erosion in West Spitsbergen. Geographical Journal, Vol. 94, No. 6, p. 447-65.

McGreevy, J.P. 1981. Some perspectives on frost shattering. Progress in Physical Geography, Vol. 5, p. 56-75.

McGreevy, J.P., and Whalley, W.B. 1982. The geomorphic significance of rock temperature variations in cold environments: a discussion. Arctic and Alpine Research, Vol. 14, No. 2, p. 157-62.

Matthes, F.E. 1900. Glacial sculpture of the Bighorn Mountains. U.S. Geological Survey. Annual Report, 21st, Pt. 2, p. 179-85.

Nussbaum, F. 1938. Beobachtungen über Gletschererosion in den Alpen und in den Pyrenäen. International Congress of Geography Proceedings. Vol. 2. International Geographical Union, p. 63-73.

Osborn, G. 1983. Characteristics of the bergschrund of an avalanche-cone glacier in the Canadian Rocky Mountains. Journal of Glaciology, Vol. 29, No. 101, p. 55-69.

Priestley, R.E., Sir. 1923. British Antarctic (Terra Nova) Expedition 1910-13. Physiography (Robertson Bay and Terra Nova Bay regions). London, Harrison and Sons.

Rapp, A. 1960. Recent development of mountain slopes in Kärkevagge and surroundings, northern Scandinavia. Geografiska Annaler, Vol. 42, Nos. 2-3. p. 65-200.

Thorn, C.E. 1980. Alpine bedrock temperatures: an empirical study. Arctic and Alpine Research, Vol. 12, No. 1, p. 73-86.

Thorn, C.E. 1982. Bedrock microclimatology and the freeze-thaw cycle: a brief illustration. Annals of the Association of American Geographers, Vol. 72, No. 1, p. 131-37.

Whalley, W.B., and McGreevy, J.P. 1985. Weathering. Progress in Physical Geography, Vol. 9, No. 4, p. 559-81.

Whalley, W.B., and others. 1984. Rock temperature observations and chemical weathering in the Hunza region, Karakoram; preliminary data, by W.B. Whalley, J.P. McGreevy, and R.I. Ferguson. (In Miller, K.J., ed. The International Karakoram Project. Vol. 2. Cambridge, etc., Cambridge University Press, p. 616-33.) 